\title{
INDONESIAN JSL STUDENTS BELIEFS ABOUT JAPANESE KANJI LEARNING AND JAPANESE KANJI LEARNING STRATEGIES
}

\author{
Aep Saeful Bachri, Dian Bayu Firmansyah, Sudjianto \\ Departemen Pendidikan Bahasa Jepang, Universitas Pendidikan Indonesia \\ Jl. Dr. Setiabudhi No. 229, Bandung 40154, Indonesia \\ *e-mail: aepsaefulbachri@upi.edu
}

First received: 13 November 2017

Final proof received: 22 December 2017

\begin{abstract}
Abstrak
Penelitian ini bertujuan untuk mengetahui tentang beliefs serta strategi belajar yang digunakan oleh mahasiswa/i Departemen Pendidikan Bahasa Jepang (DPBJ) FPBS UPI, dalam mempelajari kanji. Selain itu, penelitian ini juga bertujuan untuk meneliti tentang hubungan antara beliefs dan strategi belajar kanji yang digunakan oleh mahasiswa/i DPBJ FPBS UPI. Proses pengumpulan data dilakukan dengan menggunakan instrumen angket dan wawancara. Angket BALLI yang dikembangkan oleh Horwitz (1987) digunakan untuk meneliti tentang beliefs pembelajar dalam pembelajaran kanji, sedangkan untuk mengetahui tentang strategi belajar kanji yang digunakan oleh pembelajar, peneliti menggunakan angket SILL (Oxford 1990), yang telah dimodifikasi. Sampel dalam penelitian ini yaitu mahasiswa tingkat satu sampai tingkat tiga DPBJ, yang tercatat masih aktif mengikuti perkuliahan. Dari hasil data penelitian yang diperoleh di lapangan, diketahui bahwa secara keseluruhan pembelajar memiliki beliefs yang positif terhadap proses penguasaan Kanji serta menganggap kesulitan yang dialami dalam pembelajaran Kanji, dapat diatasi dengan peran aktif pengajar dalam pengajaran Kanji di dalam kelas. Pembelajar juga selalu melakukan evaluasi diri terhadap proses penguasaan Kanji yang sedang dilakukan, sehingga pengajar Kanji juga perlu mempertimbangkan keefektifan serta metode ajar yang digunakan. Teknik asosiasi ternyata sangat jarang digunakan pembelajar, karena dianggap tidak efektif dalam membantu proses penguasaan Kanji yang sedang dipelajari.
\end{abstract}

Kata Kunci: beliefs; strategi belajar; pemerolehan kanji

\begin{abstract}
The major purpose of this study were to find out about which kind of beliefs and learning strategies are used by Japanese as second language (JSL) students in studying Japanese character (kanji). This study was conducted by descriptive statistic method used Lickert scale type survey questionnaire called Beliefs About Language Learning Inventory (BALLI) and Strategy of Inventory Language Learning (SILL). Some short interview also conducted as a research instrument. The subject in this current research were the Japanese language student of Indonesian University of Education. Survey questionnaire result showed that overall learners have a positive beliefs on the process of acquiring kanji and also consider that the difficulties experienced in kanji learning process, can be solve by employ appropriate kanji learning strategies. They also believe that teachers have an important role in providing them a wider range of appropriate kanji learning strategies, that help them to acquire kanji in more effective ways. The significant correlation found between MetacognitiveCompensation strategies and kanji learning beliefs. While negative correlation found between Association strategies and students beliefs.
\end{abstract}

Keywords: beliefs; learning strategies; kanji acquisition 


\section{INTRODUCTION}

The Japanese language is widely learned by the student in all over the world as one of the foreign languages in this globalization era. Japanese as Second Language (JSL) also learned in Indonesia since junior high school. According to The Japan Foundation survey result from 2015, Indonesian JSL student numbers have grown significantly in this past ten years and now became the second largest in the world. This survey result was quite interesting because Indonesia was the only country in the top three that the learners don't have a Japanese/Chinese character (Kanji) background.

Bullock (1999) and Joyce (2005), stated that the writing system of Japanese language has been described as one of the most complicated in the world. Therefore, for learners that do not recognize kanji culture background such as Indonesia, kanji definitely become big issues to learn.

The greatest challenges encountered by Indonesian JSL in mastering kanji is not only a matter of memorizing huge numbers of Kanji (around 5.000 characters), the rules of writing kanji and rules about how to read a kanji in Japanese ways and Chinese ways, or kanji combinations, also have a huge impact for learners to mastering kanji (Tamamura, 2001). Therefore, it is assumed that the successful JSL learners is a learner who have a long- term success in mastering kanji.

To solve those problems, it is believed that learners beliefs about learning kanji and kanji learning strategies used, has a particular role and become one of the major factors that will guide learners to success in learning kanji (Ventura, 2007; Yacoub, 2015). Regarding Breen as cited in (Bernat \& Gvozdenko, 2005), in the classrooms context, the perception, beliefs, attitudes, and metacognitive knowledge, are some of the contributory factors in the learning process and ultimate success. Furthermore, effective language learner generally used proper learning strategy that helps them to have a good learning result (Hayati, 2015).

Many researchers have conducted research about the correlation beliefs about language learning and language learning strategy. (Bernat \& Gvozdenko, 2005) showed that cognitive and psychology personality provide a foundation for the relationship between learner beliefs and their personality. While (Saeb \& Zamani, 2013), found that students attending English institutes, used more strategies such as cognitive, metacognitive, memory, compensation and social strategies. (Kato, 2005) investigated about a relationship between language learning strategy and Japanese university students English proficiency, found that students who use 
communicative strategies were successful learners relate to TOEIC test score. He also gives practical suggestions about how to teaching English for Japanese university students and found that gender has an effect on strategy use.

Related to kanji learning beliefs and kanji learning strategies research, (Ventura, 2007) conducted research to investigated teachers and students kanji learning beliefs and their use of kanji learning strategies. Through this research, Ventura give several suggestions to the teachers that they have to give a lesson that suit the learner's beliefs and improve their teaching methods by adapting to newly kanji learning styles of their students.

The reason why the researchers are interested in conducting this research was knowing the learners beliefs about kanji and kanji learning strategies used, not only important for the learners, but also important for the teachers in order to find out what was the learners needs in kanji learning and what kind of teaching methods that can suits the learners basic needs in kanji learning.

Furthermore, another reason for conducting this study was Department of Japanese Language Education, Universitas Pendidikan Indonesia, is one of the biggest Japanese language education college in Indonesia that has become a role model for other universities in Indonesia, related to
Japanese language education development and teaching innovations.

From the description above, this study aims to determine about: (a) Indonesian University JSL learners beliefs about kanji learning; (b) kanji learning strategies used by Indonesian JSL student and (c) the correlation between Indonesian JSL learners beliefs about kanji learning and kanji learning strategies. Therefore this study was conducted to answer this following questions:

1. What are the beliefs about kanji learning held by Indonesia university JSL learners?

2. What are the primary kanji learning strategies that used by the Indonesia university JSL learners?

3. What is the relationship between the beliefs about kanji learning held by Indonesia university JSL learners and their use of kanji learning strategies?

\section{METHOD}

The descriptive statistical method applied to investigate beliefs and learning strategies used by Indonesian JSL learners. Research data collected through self-scoring report survey questionnaires about beliefs-strategy inventory for learning kanji adopted and translated from a questionnaire developed by Ventura (2007). 
A total of 54 Japanese language students (22 males, 32 females) of the first, second and third year in Indonesia University of Education participated in this research. The samples were selected on the basis of convenience and availability. All the samples have learned the Japanese language for under one year until above $9-10$ years. The samples Japanese Language Proficiency (JLPT) levels were N5 level (30 persons), N4 level (12 persons), N3 level (10 persons) and the highest level was N2 (2 persons). The participant was voluntarily asked to answer survey questionnaires about Kanji learning beliefs and Kanji learning strategies. Some of them has also interviewed for obtained research data.

\section{Research Instrument}

Survey questionnaire used in this study was an Indonesian version of beliefs-strategy inventory for learning kanji developed by Ventura (2007). This survey instrument is self-scoring report consist of 77 items and divided into 3 sections. The first section is about subjects background questionnaire (11 statements), the second section is subjected kanji learning beliefs (40 statements), and the last section is about kanji learning strategy used by samples (26). Samples should respond to each statement and all the responses are given on a 5 point Lickert-scale style from 1 (Never or Almost never true of me) to 5 (always or always true of me). Gained data computed with Statistical Package for Social Sciences (SPSS) 16.0 ver. Short interview session also conducted to selected samples, in order to deliver some questions related to the survey questionnaire result and gained a complementary data.

\section{Data Collection Procedures}

Survey questionnaire delivered in Indonesia University of Education Japanese class in May 2017, divided into three groups based on the subjects entrance year. Subject filled out the questionnaires and responded to each statement based on their experience in learning kanji. The subject then returned the questionnaire on the same day.

\section{Data Analysis Procedures}

All the data collected from the questionnaire was computed into SPSS 16.0 ver application and analyzed in three phases. First, a descriptive analysis was conducted to investigate what kind of beliefs and learning strategies used by the subject in kanji learning process. In the second phase, the relationship between each item of beliefs and used strategies was conducted by correlation analysis. The last phase has investigated the correlation between learner beliefs in 
JAPANEDU: Jurnal Pendidikan dan Pengajaran Bahasa Jepang

Vol. 2, No. 2, Desember 2017, pp. 132-142

studying kanji and kanji learning strategies using a correlation analysis. There were no missing data on this study.

\section{RESULT AND DISCUSSION \\ RESULT}

Research Question 1: What are the beliefs about kanji learning held by Indonesia university JSL learners?

To answer research question 1 , descriptive analysis was conducted to investigate beliefs about kanji held by participants. The table 1 below shows the result of the descriptive analysis of the 7 items of beliefs about kanji questionnaires.

TABLE I. BELIEFS ABOUT KANJI HELD BY LEARNERS

\begin{tabular}{|c|l|c|c|}
\hline Rank & \multicolumn{1}{|c|}{ Beliefs } & Mean & $\begin{array}{c}\text { Std. } \\
\text { Deviation }\end{array}$ \\
\hline 1 & METHOD & 4.17 & .869 \\
\hline 2 & TEACHER ROLE & 4.11 & .815 \\
\hline 3 & EFFECTIVENES & 3.85 & .979 \\
\hline 4 & APTITUDE & 3.49 & 1.207 \\
\hline 5 & CULTURE VALUE & 3.44 & 1.069 \\
\hline 6 & EMOTIONAL ASPECT & 3.12 & 1.270 \\
\hline 7 & DIFFICULTY & 2.82 & 1.136 \\
\hline
\end{tabular}

a. $(n=54)$

As seen in table 1 above it can be concluded that kanji learning method was the strongest beliefs that held by samples $(\mathrm{M}=4,17, \mathrm{SD}=0.869)$, followed by teachers role, the effectiveness of kanji learning, aptitude, culture value, emotional aspect, and the difficulties of kanji learning. In other words, the result indicates that participants in this present study believe that kanji learning method was the strongest factor that influencing the success of their kanji learning process. Tabel 1 also shows that participants believe the teachers also have an important role in kanji learning especially in providing learners a sufficient kanji learning method and encouraging them when they encounter difficulties.

Furthermore, descriptive analysis result indicates that kanji learning method (item 16, $30,25,38)$ such as "I can become proficient in reading and writing kanji learning if I study hard enough" (M=4.74, $\mathrm{SD}=.442)$, "Regular practices and constant review are important in the study of kanji" $(\mathrm{M}=4.52, \quad \mathrm{SD}=.504)$, "Learning kanji is mainly a matter of learning vocabulary words" $(\mathrm{M}=4.30, \mathrm{SD}=.743)$ or "When studying kanji, it is important to memorize their kun-yomi (native Japanese reading)" ( $\mathrm{M}=4.24, \mathrm{SD}=.432)$ was the main factor to success in mastering kanji. While learners also believe that teachers role such as "Teachers should use a variety of methods when teaching kanji" ( $\mathrm{M}=4.61, \mathrm{SD}=.492)$, "Teachers should use games and other activities to make their kanji classes more interesting" $\quad(\mathrm{M}=4.43, \quad \mathrm{SD}=.499) \quad$ and "Teachers should explain new kanji in detail (meaning, origin, etc)" $(\mathrm{M}=4.35, \mathrm{SD}=.588)$ as an important factor that can help them mastering kanji in more effective ways. Moreover, participants also believe that 
students with Chinese or Japanese character background have a better ability in memorizing and writing kanji (item 9 and $10)$.

Otherwise, the difficulties encountered by participants in learning kanji were not big issues for them. As is seen in statements 39 , 40, 12 such as "I don't like learning how to read kanji" (M=1.96, $\mathrm{SD}=.846)$, "I don't like learning how to write in kanji" (M=2.09, $\mathrm{SD}=1.014)$ and "Learning how to read and write kanji is an obstacle to learning the Japanese language" ( $\mathrm{M}=2.63, \mathrm{SD}=1.104)$, this emotional aspect and difficulties has a negative influence in kanji learning. Culture value such as "It is important to study kanji because my country has close (economic, political, cultural) lies with Japan" (item 32) also does not have a significant impact for their learning kanji process $(\mathrm{M}=3.06$, $\mathrm{SD}=1.089$ ).

Tabel 2 shows the correlation between the 7 items of beliefs about kanji learning.

TABLE II. CORRELATIONS BETWEEN KANJI BELIEF

\begin{tabular}{|c|c|c|c|c|c|c|c|}
\hline Belief & B1 & B2 & B3 & B4 & B5 & B6 & B7 \\
\hline B1 & 1 & $1.000^{-}$ & 383 & $676^{* *}$ & 081 & $435^{* *}$ & $617^{* *}$ \\
\hline B2 & $\begin{array}{r}- \\
1.000^{*}\end{array}$ & 1 & 370 & $689^{* *}$ & 067 & $448^{* *}$ & $630^{* * *}$ \\
\hline B3 & 383 & 370 & 1 & $602^{* *^{*}}$ & 226 & $736^{* * *}$ & 324 \\
\hline B4 & $676^{* *}$ & $689^{* * *}$ & $602^{* *}$ & 1 & $961^{* * *}$ & 025 & 126 \\
\hline B5 & 081 & 067 & 226 & $961^{* *}$ & 1 & $665^{* *}$ & 140 \\
\hline B6 & $435^{*}$ & $448^{*}$ & $736^{* *}$ & 025 & $665^{* *}$ & 1 & 345 \\
\hline B7 & $617^{* *}$ & $630^{* *}$ & 324 & 126 & 140 & 345 & 1 \\
\hline
\end{tabular}

B1=Culture Value, B2=Difficulty, B3=Aptitude, B4=Effectiveness, B5=Emotional Aspect, B6=Teacher role, B7=Method

$* * p<.01 * p<.05$
As seen in table 2 above, there are significant correlation between Effectiveness with Culture Value ( $r=.67$, $p<.01)$, Difficulty $(r=.68, p<.01)$, Aptitude $(r=.60, p<.01)$. Emotional Aspect has stong correlation with Effectivenes ( $r=.96$, $p<.01)$. Teacher role has strong correlation with Culture Value $(r=.43, \quad p<.01)$, Difficulty $(r=.44, p<.01)$, Aptitude $(r=.73$, $p<.01)$, Emotional Aspect $(r=.66, p<.01)$. Method has a strong correlation with Culture Value $(r=.61, p<.01)$, Difficulty $(r=.63, p<.01)$. Difficulty has negative correlation with Culture Value ( $r=-1.0$, $p<.05)$.

Correlation analysis result shows that learners held strong emotional aspect and concerning the effectiveness of kanji learning tended to master kanji more better than the others. While learners dealing with culture value such as seeking a relationship between Japanese culture and kanji learning will encounter more difficulties in mastering kanji.

Research Question 2: What are the primary kanji learning strategies used by Indonesia university JSL Learners?

Descriptive analysis was also conducted to investigate kanji learning strategies used by participants in order to answer research question 2 . The table 5 below shows the result 
of the descriptive analysis of the 5 items of beliefs about kanji questionnaires.

TABLE III. KANJI LEARNING STRATEGIES USED BY LEARNERS

\begin{tabular}{|c|l|c|c|}
\hline Rank & \multicolumn{1}{|c|}{ Strategy } & Mean & $\begin{array}{c}\text { Std. } \\
\text { Deviation }\end{array}$ \\
\hline 1 & COMPENSATION & 3.91 & 1.120 \\
\hline 2 & CONTEXT STRATEGY & 3.45 & 1.410 \\
\hline 3 & COGNITIVE & 2.93 & 1.369 \\
\hline 4 & META-COGNITIVE & 2.62 & 1.158 \\
\hline 5 & ASSOCIATION & 2.34 & 1.129 \\
\hline
\end{tabular}

Table 3 shows that Compensation Strategy was the most preferred strategy by samples $(M=3,91, S D=1.120)$ for learning kanji, followed by Context Strategy, Cognitive Strategy, Meta-Cognitive Strategy and Association Strategy. In other words, the result indicates that participants in this present study were relying on the dictionary when they had encountered difficulties in term of reading or writing kanji.

Descriptive analysis result indicates that Cognitive Strategies (item 21, 16, 17, 11) such as "I write the reading of unfamiliar kanji beside or on top of each character to help me remember" $(\mathrm{M}=3.81, \mathrm{SD}=1.304)$, “I memorize a newly-learned kanji by trying to remember what they look like" $(\mathrm{M}=3.57$, $\mathrm{SD}=1.092$ ) or "I memorize a newly-learned kanji by writing them repeatedly" ( $\mathrm{M}=3.54$, $\mathrm{SD}=1.432$ ) was frequently employed by participants when they have to memorize a new kanji. Participants also used context strategies such as "I try to guess the meaning of unfamiliar kanji with the use of context clues" $(\mathrm{M}=3.62, \quad \mathrm{SD}=1.200), \quad$ "I try to remember newly-learned kanji as a part of compound words rather than isolated characters" $(\mathrm{M}=3.06, \mathrm{SD}=1.188)$ or "I try to use a newly-learned kanji as much as possible (in sentences and compositions)" ( $M=2.74$, $\mathrm{SD}=1.031$ ) as one of the effective ways to mastering a new kanji. But the most frequently used by the participant when they didn't know how to read and find out the meaning of a new kanji was used the dictionary. This was the particular strategy that always used by learners $(\mathrm{M}=3.21$, $\mathrm{SD}=1.190$ ).

Otherwise, Association Strategies such as "I try to classify kanji I know by shapes" $(\mathrm{M}=2.33, \mathrm{SD}=1.064)$, "I try to classify kanji I know by meaning" $(\mathrm{M}=2.31, \mathrm{SD}=1.025)$ or "I try to remember what page or what place I first saw a particular character" $(\mathrm{M}=2.33$ $\mathrm{SD}=1.303$ ). Therefore, Associaton Strategy was the unfamiliar strategies among the participants, especially when its related with how to read kanji in Onyomi or Chinese Reading.

Tabel 4 shows the SPSS result on the coefficient of correlation between the 5 items of kanji learning strategies. 
Dian Bayu Firmansyah, Aep Saeful Bachri, Sudjianto, Indonesia JSL Students Beliefs About Japanese Kanji Learning and Japanese Kanji Learning Strategies

TABLE IV. CORRELATIONS BETWEEN KANJI LEARNING STRATEGY

\begin{tabular}{|c|c|c|c|c|c|}
\hline Strategy & S1 & S2 & S3 & S4 & S5 \\
\hline S1 & 1 & $.870^{* *}$ & .277 & $1.000^{* *}$ & $-1.000^{*}$ \\
\hline S2 & $.870^{* *}$ & 1 & $.948^{* *}$ & $1.000^{* *}$ & $-1.000^{*}$ \\
\hline S3 & .277 & $.948^{* *}$ & 1 & $1.000^{* *}$ & $-1.000^{*}$ \\
\hline S4 & $1.000^{* *}$ & $1.000^{* *}$ & $1.000^{* *}$ & 1 & $-1.000^{*}$ \\
\hline S5 & $-1.000^{*}$ & $-1.000^{*}$ & $-1.000^{*}$ & $-1.000^{*}$ & 1 \\
\hline
\end{tabular}

$\mathrm{S} 1=$ Context Strategies, $\mathrm{S} 2=$ Association Strategies, $\mathrm{S} 3=$ Cognitive Strategies, S4=Meta-Cognitive Strategies, S5=Compensation Strategies

d. $* * p<.01 * p<.05$

Table 4 shows that, there are significant correlation between Association Strategies with Context Strategies $(r=.87, \quad p<.01), \quad$ Cognitive Strategies $(r=.94, p<.01)$, Meta-Cognitive Strategies $(r=1.00, \quad p<.01)$. Meta-Cognitive Strategies has strong correlation with Context Strategies $(r=1.00$, $p<.01)$, Association Strategies $(r=1.00, p<.01)$, Cognitive Strategies $(r=1.00, p<.01)$. Compensation Strategies has negative correlation with another strategies such as Context, Association, Cognitive, Meta-Cognitive $(r=-1.0, p<.05)$.

In the other words, learners that employed MetaCognitive Strategies combine with Context, Association and Cognitive Strategies such as doing an evaluation on the kanji learning process and used to practices more often in terms of writing and reading kanji is tended to perform the Japanese language better than the others.

Research Question 3: What is the relationship between the beliefs about kanji learning held by Indonesia university JSL learners and their use of kanji learning strategies?

To answer research question 3, correlation analysis was conducted to investigate a correlation between beliefs about kanji held by participants and kanji learning strategies used, as seen in table 5 below.
TABLE V. CORRELATIONS BETWEEN KANJI LEARNING STRATEGY USED AND BELIEFS ABOUT KANJI LEARNING

\begin{tabular}{|l|l|l|l|l|l|}
\hline $\begin{array}{l}\text { St/ } \\
\text { B1 }\end{array}$ & $\mathrm{S} 1$ & $\mathrm{~S} 2$ & $\mathrm{~S} 3$ & $\mathrm{~S} 4$ & $\mathrm{~S} 5$ \\
\hline $\mathrm{B} 1$ & .484 & -.078 & -.586 & $.972^{* *}$ & $.987^{* *}$ \\
\hline $\mathrm{B} 2$ & -.503 & .058 & .569 & -.977 & -.984 \\
\hline B3 & $.727^{* *}$ & $.747^{* *}$ & -113 & $.934^{* *}$ & $.724^{* *}$ \\
\hline B4 & -.446 & -.090 & -.419 & .268 & .619 \\
\hline B5 & -.893 & -.554 & -.670 & -.994 & -.960 \\
\hline B6 & .052 & -.084 & .411 & -.605 & -.866 \\
\hline B7 & $.844^{* *}$ & .286 & .595 & -.356 & -.689 \\
\hline
\end{tabular}

B1=Culture Value, B2=Difficulty, B3=Aptitude, B4=Effectiveness, B5=Emotional Aspect,B6=Teacher role, B7=Method

$\mathrm{S} 1=$ Context Strategies, S2=Association Strategies, S3= Cognitive Strategies, S4=Meta Cognitive Strategies, $\mathrm{S} 5=$ Compensation Strategies

$* * p<.01 * p<.05$

Table 5 shows that there is a positive correlation between Aptitude with Context Strategies $\quad(r=.72, \quad p<.01)$, Association Strategies $(r=.74, p<.01)$, Meta-Cognitive Strategies $\quad\left(r=.93, \quad p^{<.01)} \quad\right.$ and Compensation Strategies $(r=.72, p<.01)$. Significant correlation also can be seen among Method with Context Strategies $(r=.84, p<.01)$. the highest significant and positive correlation was between Culture Value with Meta-Cognitive and Compensation strategies.

From the analysis result, it can be concluded that appropriate learning strategies will lead learners to successful in kanji learning even if they have negative belief about kanji learning.

\section{DISCUSSION}

The first part that must be discussed in this study is explaining about student's beliefs 
held in Japanese Kanji learning. This study

result showed that the strongest beliefs held by students were Kanji learning method. Most of the students were motivated to learn Kanji and believes that Kanji learning process can successfully do by applying a proper learning method to their learning style (Somchai, 2008).

Additionally, teacher role was the second belief held by Indonesian JSL learners. Most of the students agree that teachers have an important part in their kanji acquisition process, that will drive the learners to hold or keep on the positive beliefs in order to improve their learning achievement (Hayati, 2015). This current study also found that participants agreed that various activities for teaching such as kanji game, using teaching multimedia etc, could lead learners into more effective ways to remember kanji and enhance their learning motivation (Ventura, 2007; Somchai, 2008).

The next part to be discussed was the kanji learning strategy used by learners. From the findings, it can be observed that Indonesian JSL learners were rely on dictionary when they encountered a problems in remembering a newly-learned kanji. This result is contradictive with Ventura (2007) findings, which shows that this strategy was the less strategy preffered by Philipines Japanese learners.
The second most preffered strategy was context strategy. Within this strategy, Indonesia JSL learners liked to try to find out a meaning of unfamiliar kanji by guessing the context of the sentences. In many occasion, they revealed that they can't clearly read some kanji but they can guess the meaning of the phrases by seeing full context of the sentences.

And the last part to be discussed was the correlation between beliefs about kanji learning and kanji learning strategies. The result of the current study revealed that there are positive and significant correlation between these two variables, especially related to method and aptitude to context strategies. This finding shows that Indonesian JSL learners with no Japanese character background, attach greater importance of learning and teaching method to their kanji learning process (Ventura, 2007).

\section{CONCLUSIONS}

According to the result of the present study, there were several suggestions for teachers and Indonesian JSL learners. First of all, teachers have to understand beliefs about kanji learning held by learners. With the better understanding of learners beliefs, teachers can understand what the students need in learning kanji and can provide more effective learning method according to 
learners situation. This will lead both the teachers and learners to effective ways of teaching and learning.

This present study also found significant and positive correlation among beliefs about kanji learning and kanji learning strategies. Therefore, teachers have an important role not only teaching and providing various strategies for learning kanji but also should try to assisting learners to develop positive beliefs that can lead into successful kanji learning and avoid them to hold negative beliefs that will influence to their kanji learning process.

\section{ACKNOWLEDGEMENTS}

We would like to acknowledge Lembaga Penelitian dan Pengabdian pada Masyarakat (LPPM) that supported us through their research grant.

\section{REFERENCES}

[1] Moore, R., Lopes, J., 1999. Paper templates. In TEMPLATE'06, 1st International Conference on Template Production. SCITEPRESS.

[2] Smith, J., 1998. The book, The publishing company. London, $2^{\text {nd }}$ edition.

[3] Bullock, B., 1999. Sci.lang.japan frequently asked question. Available online at: http://www.sljfaq.org/afaq/afaq- full.html [September 27 $7^{\text {th }} \quad 2017$ Accesed]

[4] E. Bernat, I. Gvozdenko, "Beliefs about language learning: current knowledge, pedagogical implications and new research directions", TESLEJ, 2005, vol. 9, no.1, pp. 1-21.

[5] F. Saeb \& E. Zamani, "Language learning strategies and beliefs about language learning in high school students and students attending English institutes: are they different?", Canadian Center of Science and Education, English Language Teaching, 2013, vol. 6, no. 12, pp. 7986.

[6] F. Tamamura, "Nihongogaku o manabu hito no tameni". Japan : Sekai Shisousha, 2001.

[7] F. Ventura, "Filipin-jin nihongo gakushusha to kyoshi no kanji gakushu ni taisuru beliefs to sutorateji shiyo - kanji kyoiku no kaizen no tame ni-. Nihon Gengo Bunka Kenkyukai Ronshuu No. 3, 2007 pp. 141-168.

[8] Joyce, T., 2005. Two-kanji compound in the Japanese mental lexicon. Available online at: http://www.valdes.titech.ac.jp/ [September 27 ${ }^{\text {th }}, 2017$ Accesed] 
[9] M. A. Yacoub, O. Yacoub and Y. Yacoub, "Learning strategies (SILL), Beliefs (BALLI) and styles (R\&L) of succesful learners of english as a second language", in International Journal of Social Science and Humanities Research, 2015, vol. 3, no. 1, pp. 355-362

[10] N. Hayati, "A study of English language learning beliefs, strategies and English academic achievement of the ESP students of STIENAS Samarinda", Dinamika Ilmu, 2015, vol. 15, no. 2, pp. 297-323.

[11] N. Lin, S. Kajita and K. Mase, "Storybased CALL for Japanese Kanji Characters: A Study on Student Learning Motivation". The JALT CALL Journal, 2007, vol. 3, no. 1-2, pp. 25-44.

[12] S. Kato, "How language learning strategies affect English proficiency in Japanese university students", Bunkyo Gakuin Daigaku Kenkyu Kiyo, 2005, vol. 7, no. 1, pp. 239-262

[13] The Japan Foundation. (2015). Survey Report on Japanese-Language Education Abroad 2012. Japan: The Japan Foundation. Available online: https://www.jpf.go.jp/j/project/japanes e/survey/result/dl/survey_2015/all.pdf (accesed: September, 27 2017) 